\title{
Knowledge Level of ATMA and Non-ATMA Farmers about Improved Practices of Wheat Cultivation in Barabanki (U.P), India
}

\author{
Naveen Kumar*, S. R. Yadav, Abhishek Mishra and Siddhant Mishra \\ Department of Agricultural Extension, Chandra Shekhar Azad University of Agriculture \& \\ Technology, Kanpur, India \\ *Corresponding author
}

\section{Keywords}

ATMA, converge, Farmers, Wheat crop, Agriculture development, cultivation technology etc.

Article Info

Accepted:

18 January 2020

Available Online:

10 February 2020

\section{A B S T R A C T}

ATMA focused on a bottom-up planning process in order to make the entire extension system farmer-driven and farmer accountable. This has helped to strengthen research and extension capabilities, restructure public extension services and test new institutional arrangements for technology transfer with the involvement of all the stakeholders of Government and Non-Governmental agencies at the district level. The state of Uttar Pradesh is having 75 districts. Out of these districts, district Barabanki were selected purposively for study. The total number of blocks in the Barabanki district is fifteen (15). Out of there are three blocks operated this project, one (1) block namely, Banikodar were selected randomly. ATMA farmers were selected from a prepared list and three villages were selected from a selected block, similarly, three villages were also selected from the same selected block that is not covered under ATMA project for a selection of NonATMA farmers. Therefore, a total number of six villages were selected to select respondents. With the objective of the knowledge level of ATMA and Non-ATMA farmers about improved practices of wheat cultivation, a total of 120 farmers in which 60 ATMA farmers and 60 Non-ATMA farmers were selected. The data collected from the farmers with the help of well-prepared interview schedule. It was stated the majority (53.33 per cent) of the farmers from ATMA category had a medium extent of knowledge followed by 26.67 per cent had high and 20 per cent had a low extent of knowledge. While in case of Non-ATMA category the majority (45 per cent) of farmers had a medium extent of knowledge followed by 33.33 per cent were having a low extent of knowledge and only 21.67 per cent have a high extent of knowledge, respectively about improved wheat crop technology. It was concluded that farmers of the ATMA category showed a higher extent of adoption of improved wheat cultivation technologies pertaining to wheat cultivation practices than those of the Non-ATMA category.

\section{Introduction}

India has come a long way from the situation 'living from ship to mouth' to food selfsufficiency'. Agriculture plays a vital role in the development of the country. There are many technologies and practices evolved in agriculture for increasing the production and improving the status of farmers. The agricultural extension also helps to 
disseminate the agricultural information to the farmers. Initially, the focus of extension was on human and community development. A number of extension programmes have been implemented over the years during both pre and post-Indian independence for the delivery or transfer of agricultural technology to the farmers through non-formal education some of which include the Gurgaon project, Marthandom project, Sri Niketan project, NES, CDP, IADP, T\&V System. These projects have ensured all-round holistic development of the rural populace. Thus, Extension Reforms in India launch the new Scheme "Support to State Extension Programmes for Extension Reforms" in 200506 and more commonly known as the ATMA. It is the National Institute of Agricultural Extension Management (MANAGE), which played a pivotal role in implementing the NATP project that has been given responsibility for bringing about this change. On the basis of experience gained during the implementation of the Extension Reforms Scheme from 2005 to 2009, the Government of India has revised the ongoing Centrally Sponsored Scheme and named Modified "Support to State Extension Programmes for Extension Reforms" Scheme in April 2010, which was revamped, expanded and strengthened comprehensively with the objective of strengthening the extension machinery and utilizing it for synergizing the interventions under these schemes under the umbrella of Agriculture Technology Management Agency (ATMA). It is currently operational in 639 districts and the remaining rural districts are also proposed to be covered. ATMA was established at the district level as an autonomous organization registered under 'Societies Registration Act 1860'. It strengthens the district level planning; using technology to reach out to the farmers, raising the capability of rural poor to conserve and manage their livestock and fisheries resources and derive sustainable incomes; link small farmers to markets; promote decentralized participatory research as well as knowledgeintensive alternatives (ATMA guidelines, 2014 under NMAET). The district-level ATMA project is often highlighted as an innovative model of public-sector agricultural extension involving decentralization as well as participatory and bottom-up approaches. ATMA represents a unique institutional platform that aims to integrate at the district level the weakly linked research and administration arms of public-sector agricultural extension in India. The key institution in implementing this new approach was the ATMA which was responsible for facilitating and coordinating "farmer-led" extension activities within each district.

\section{Key elements of the ATMA}

"Farming-systems" approach which required the integration of extension activities across the different line departments.

Organizing small-scale farmers, including women, into farmer interest groups (FIGs).

Decentralizing extension decision-making down to the district and block levels including farmer input.

Linking the farmer-interest groups to markets

Introduction for the purpose of increasing farmer income and creating rural employment. ATMA focused on a bottom-up planning process in order to make the entire extension system farmer-driven and farmer accountable. This has helped to strengthen research and extension capabilities, restructure public extension services and test new institutional arrangements for technology transfer with the involvement of all the stakeholders of Government and NonGovernmental agencies at the district level. New institutional arrangements were created 
at different levels to put the project into operation.

Asif et al., (2012) revealed the extension agent's role should be more proactive in disseminating important information related to dairy farming, as well as milk marketing in the southern part of West Bengal. Kumar et al., (2012) reported that quantity seed was distributed among the Tribal farmers of Jharkhand. Majority of the farmers of the state are unaware about the importance of quality seed (Paddy, Maize, Niger, RapeseedMustered and Wheat) were distributed among 100 farmers.

\section{Materials and Methods}

The study was conducted in the Barabanki district in the state of UP in January 2018. Out of the total number of blocks in Barabanki district only one block namely, Banikoder was selected for the study. A cumulative list of villages was prepared on the basis of farmers who received training under ATMA in recent year (list of villages collected from ATMA office, Barabanki). The villages having a maximum number of ATMA farmers were selected from a prepared list and three villages namely Mawaiya, Dandupur and Deviganj were selected, similarly three villages namely, Pehla, Jarauli and Lakadiya were also selected from the same block that is not covered under ATMA project for a selection of Non-ATMA farmers. So, the total number of six villages was selected to select respondents. With the objective of knowledge level of ATMA and Non-ATMA farmers about improved practices of wheat cultivation, total 120 farmers in which 60 ATMA farmers were selected through Probability Proportion to Size Method (PPS) from the selected villages (list of beneficiaries of one block namely, Barabanki collected from ATMA office, Barabanki) and 60 Non-ATMA farmers (untrained) also selected from the same block's villages those are not covered under ATMA project. The data collected from the respondents with the help of well-prepared interview schedule.

\section{Results and Discussion}

Table 1 below reveals that the profile of the farmers by Education, Size of landholding and Occupation. Out of the total farmers in terms of education majority of the ATMA group under the category of Intermediate, primary to High School and Graduate level education was (28.33 per cent) (25.00 per cent) and (13.33 per cent) whereas majority of the Non-ATMA group under the same category were ( 23.33 per cent), (15 per cent) and (10 per cent), respectively. And the other hand illiteracy percentage (18.33 per cent) was low in the ATMA group than of NonATMA group (25 per cent). Further studied that majority of the farmers in the ATMA and Non-ATMA group (53.34 per cent) and (30 per cent), respectively were having marginal and small size of landholding followed by the (10 per cent) and (6.66 per cent) belong to medium and large size of landholding, respectively of the ATMA group, further (50 per cent) marginal and (36.66 per cent) small size of landholding farmers followed by the (8.34 per cent) and (5 per cent) belong to medium and large size of landholding of the Non -ATMA group.

There were (30 per cent) of ATMA farmers were engaged in business and farming followed by farming as a sole profession (20 per cent), service and farming (16.67 per cent) and caste profession and farming (18.33 per cent), labour and farming (15 per cent), Similarly, the majority ( 30 per cent) of NonATMA farmers were engaged in business and farming followed by farming as a sole profession (23.33 per cent), labour and farming (18.33 per cent), service and farming 
(6.66 per cent) and caste profession and farming (15 per cent).

The Table 2 reveals that the majority of the trained farmers with their mean score (0.90) were possessed knowledge about pesticides and weedicides followed by field preparation (0.82), sowing technique (0.80), harvesting and storage (0.77) and irrigation and fertilization (0.75), respectively. Likewise, the majority of the untrained farmers with their mean score $(0.77)$ were possessed knowledge about pesticides and weedicides followed by sowing technique (0.71), field preparation (0.69) and harvesting and storage (0.54), respectively.

Table.1 Profile of the ATMA and Non-ATMA farmers

\begin{tabular}{|c|c|c|c|c|c|c|}
\hline \multirow[t]{2}{*}{ S. No. } & \multirow{2}{*}{\multicolumn{2}{|c|}{ Variables }} & \multicolumn{2}{|c|}{ ATMA Farmers } & \multicolumn{2}{|c|}{ Non-ATMA Farmers } \\
\hline & & & Frequency & Percentage & Frequency & Percentage \\
\hline \multirow[t]{5}{*}{1.} & \multirow[t]{5}{*}{ Education } & Illiterate & 11 & 18.34 & 15 & 25.00 \\
\hline & & Up to Primary & 9 & 15.00 & 16 & 26.66 \\
\hline & & Primary to High School & 15 & 25.00 & 14 & 23.34 \\
\hline & & Intermediate & 17 & 28.33 & 9 & 15.00 \\
\hline & & Graduate & 8 & 13.33 & 6 & 10.00 \\
\hline \multirow[t]{4}{*}{2.} & \multirow{4}{*}{$\begin{array}{l}\text { Size of land } \\
\text { holding }\end{array}$} & Marginal (below 1 ha.) & 32 & 53.34 & 30 & 50 \\
\hline & & $\begin{array}{c}\text { Small } \\
\text { (1 to } 2 \text { ha.) }\end{array}$ & 18 & 30 & 22 & 36.66 \\
\hline & & $\begin{array}{l}\text { Medium } \\
\text { ( } 2 \text { to } 5 \text { ha.) }\end{array}$ & 6 & 10 & 5 & 8.34 \\
\hline & & $\begin{array}{c}\text { Large } \\
\text { (Above } 5 \text { ha.) }\end{array}$ & 4 & 6.66 & 3 & 5 \\
\hline \multirow[t]{5}{*}{3.} & \multirow[t]{5}{*}{ Occupation } & labor and Farming & 9 & 15 & 11 & 18.33 \\
\hline & & $\begin{array}{c}\text { Caste Profession and } \\
\text { Farming }\end{array}$ & 11 & 18.33 & 9 & 15 \\
\hline & & Business and Farming & 18 & 30 & 22 & 30 \\
\hline & & $\begin{array}{c}\text { Farming as a Sole } \\
\text { Profession }\end{array}$ & 12 & 20 & 14 & 23.33 \\
\hline & & Service and Farming & 10 & 16.67 & 4 & 6.67 \\
\hline \multicolumn{3}{|c|}{ Total } & 60 & 100 & 60 & 100 \\
\hline
\end{tabular}

Table.2 Distribution of farmers with respect to their knowledge level about improved practices of wheat cultivation

\begin{tabular}{|c|c|c|c|}
\hline \multirow{2}{*}{$\begin{array}{c}\text { S. } \\
\text { No }\end{array}$} & Practices of Wheat cultivation & \multicolumn{2}{|c|}{ Mean Score } \\
\hline $\mathbf{1}$ & & ATMA Farmers & Non-ATMA Farmers \\
\hline $\mathbf{2}$ & Field Preparation & 0.82 & 0.69 \\
\hline $\mathbf{3}$ & Sowing Technique & 0.80 & 0.71 \\
\hline $\mathbf{4}$ & Irrigation and Fertilization & 0.75 & 0.68 \\
\hline $\mathbf{5}$ & Pesticides and Weedicides & 0.90 & 0.77 \\
\hline
\end{tabular}


Table.3 Distribution of farmers with respect to their overall knowledge about improved practices of wheat cultivation

\begin{tabular}{|c|c|c|c|c|c|c|}
\hline \multirow[t]{3}{*}{ S.No. } & \multirow[t]{3}{*}{ Categories } & \multicolumn{2}{|c|}{ ATMA Farmers } & \multirow[t]{3}{*}{ Categories } & \multicolumn{2}{|c|}{ Non-ATMA Farmers } \\
\hline & & \multirow{2}{*}{$\begin{array}{c}\text { Responden } \\
\text { ts }\end{array}$} & \multirow[t]{2}{*}{ Per cent } & & & \\
\hline & & & & & Respondents & Per cent \\
\hline 1. & Low (Scores less than 19) & 12 & 20 & $\begin{array}{c}\text { Low } \\
\text { (Scores less than 19) }\end{array}$ & 20 & 33.33 \\
\hline 2. & Medium (Scores 19to 28) & 32 & 53.33 & $\begin{array}{l}\text { Medium (Scores 19to } \\
25 \text { ) }\end{array}$ & 27 & 45 \\
\hline 3. & High (Scores 28 \&more) & 16 & 26.67 & $\begin{array}{l}\text { High (Scores } 25 \\
\text { \&more) }\end{array}$ & 13 & 21.67 \\
\hline & Total & 60 & 100 & Total & 60 & 100 \\
\hline
\end{tabular}

Fig.1

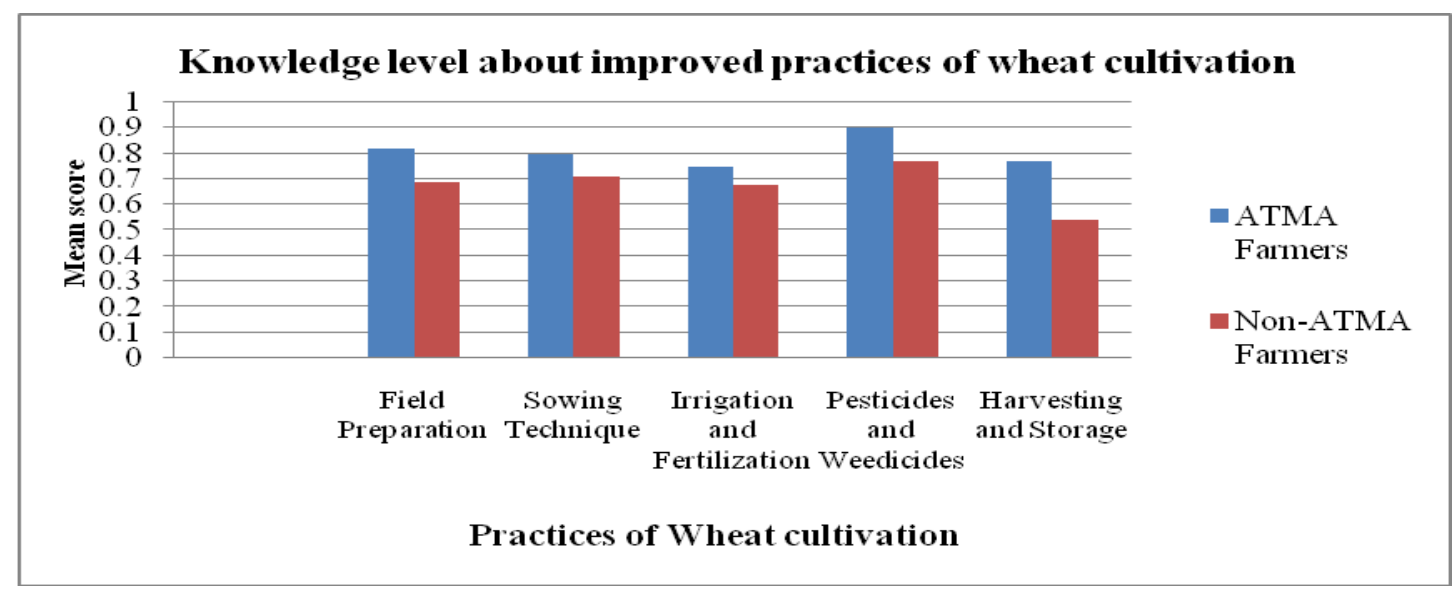

Fig.2

It is evident from Table 3 that majority (53.33 per cent) of the farmers from ATMA category had a medium extent of knowledge followed by (26.67 per cent) had high and (20 per cent) had a low extent of knowledge. While in case of Non-ATMA category the majority (45 per cent) of farmers had a medium extent of knowledge followed by (33.33 per cent) were having a low extent of knowledge and only (21.67 per cent) have a high extent of knowledge, respectively about improved wheat crop technology. The finding is in line with the findings of Dubey and Srivastava (2007), Chaoudhary and Yadav (2012) and Meena et al., (2014).

In conclusion ATMA is an autonomous body responsible for delivering agricultural and allied extension services to the farmers at the district level. It is revealed that the Farmers of ATMA category also showed a higher extent of knowledge. Majority of ATMA farmers belong to the medium category of knowledge of practices of wheat cultivation. These farmers obtain a higher return from their production area. This could be due to the exposure of the ATMA farmers to knowledge through on-farm trial conducted by ATMA. The Non-ATMA farmer lacked this opportunity and hence, they showed the lower extent of knowledge of these technologies. So it should be cover all farmers in particular villages for improving the awareness and knowledge level of farmers.

\section{References}

Asif, M., Gupta, J., Kumar, R., Senthi and Subash, S. (2012). Linkage pattern among actors of milk production innovation system in coastal saline soil zone of West Bengal (India). Journal of Global Communication. 5(1): 39-43.

Barman, U. and Kumar, B. (2012). Knowledge level of extension personnel under ATMA regarding their facilitation skills. Agricultural Science Digest - A Research Journal. 32 (3): 145-148.

Choudhary, S. and Yadav, J.P. (2012) Knowledge level of the beneficiary and notbeneficiary farmers about improved mungbean production technology.Indian Res. J. Ext.Edu.12 (2): 70-73.

Dubey, A.K. and Srivastava, J.P.. (2007) Effect of the training programme on knowledge and adoption behaviour of farmers on wheat production technologies. Indian Res. J.Ext. Edu. 7 (2 \& 3): 41-43.

Jahagirdar, K.A. and Balasubramanya, A.S. (2011) Comparative study on communication behaviour of extension personnel working in government and private sectors. Journal of Global Communication. 4 (2): 122-126.

Kumar, S., Purushottam and Yadav, V.K. (2012) Knowledge and attitude of hill farmers towards improved agricultural practices. Indian Journal of Extension Education. 48 (3\&4): 26-29.

Meena, L.K., Sirohiya, L., Kant, S., Bairwa, S.L. \& Jhajharia, (2014) A. Impact of KVK training programmes on knowledge and adoption of chickpea production innovations in Madhya Pradesh, India. Journal of Extension Systems.30 (1).

Naidu, J. Y. N.; Philip, H.; Asokan, M.; Bala Subramanian, R.; Duraisamy, M. R. (2016) The present study was carried out in Andhra Pradesh state to explore the constraints faced by the extension functionaries at each level of decentralized management. Journal of Extension Education; 28(4):5768-5774.

Sahu, R.P., Prasad, A. and Ram D. (2010) Adoption of improved wheat cultivation technologies in Unnao district of Uttar Pradesh.Indian Res. J. Ext. Edu. 10 (2): 25-27.

Kaushal Kumar Jha and Das Rajib (2017) Knowledge level of Potato farmers \& its determinants. Conference: Impact of agricultural technologies in enhancing growth and income, at $\mathrm{J} \& \mathrm{~K}$. 


\section{How to cite this article:}

Naveen Kumar, S. R. Yadav, Abhishek Mishra and Siddhant Mishra. 2020. Knowledge Level of ATMA and Non-ATMA Farmers about Improved Practices of Wheat Cultivation in Barabanki (U.P). Int.J.Curr.Microbiol.App.Sci. 9(02): 2609-2615. doi: https://doi.org/10.20546/ijcmas.2020.902.298 